\title{
Anglo-American Credit Scoring and Consumer Debt in the Subprime Mortgage Crisis of 2007 as Models for Other Countries?
}

\author{
Thomas F. Ruddy \\ Empa Swiss Federal Labs. Lerchenfeldstr. 5, \\ $\mathrm{CH} 9014$ St.Gallen, Switzerland \\ thomas.ruddy@empa.ch
}

Contribution to the tripleC-special issue "Capitalist Crisis, Communication \& Culture", edited by Christian Fuchs, Matthias Schafranek, David Hakken, Marcus Breen

\begin{abstract}
The system of credit scoring has been built up in recent times on the basis of a compromise struck between individuality and surveillance in ways that boosted consumption through consumer debt. This paper considers the role of credit scoring in the recent financial crisis, concluding that even if credit scoring had worked as intended under its own terms, the practice would not have been enough to limit the defaulting of mortgage borrowers under conditions of falling house prices. The broader economic problem is the crippling amount of consumer debt involved; hence the paper places credit scoring in the larger explanatory framework of consumer debt and, more generally, consumerism in its more problematic form. The sorting accomplished by credit scoring is open to abuses in the marketplace, unless it is tempered by the application of guardrails by a regulatory authority. As cultures beyond the Anglo-American sphere adopt this practice, guardrails like those applied to credit scoring in America are needed; as even the current U.S. Administration has acknowledged, the existing guardrails will have to be complemented by stricter social standards. The paper provides a derivation of the theoretical background on credit scoring as surveillance, and includes a literature survey.
\end{abstract}

Keywords: surveillance, credit risk, regulation, credit scoring, privacy

The subprime mortgage crisis of 2007 and attendant "credit crunch" followed upon an increase in consumer debt reinforced by credit scoring. Scoring is a calculative technique based on actuarial principles and made possible on a large scale by computer technology. The designers of such a system in their actions determine the later consequences that will result from application of the technology, whether the consequences come about as anticipated or otherwise. Analysis of the subprime mortgage crisis of 2007 reveals that technology was one element in a whole mix of causes, i.e. a rise in the sophistication of calculative techniques, had been allowed to affect the real economy practically unfettered by any regulation. But perhaps better regulation in itself would not be enough of a solution to mitigate the risks of adverse social consequences or an economic crash; perhaps the social construction of technology should also be considered as a contributing factor in addition to better regulation.

This paper will trace the rise of consumer debt reinforced by credit scoring practiced as a result of a trade-off between individuality and surveillance that society had made. How much social sorting was considered acceptable? The cast of players includes consumers as borrowers and financial companies as both lenders and employers of system designers and actuaries; regulators play only a minor role. The trade-off reached between individuality and surveillance amounted to a consensus on the degree of social sorting that the society could accept as necessary sanctions against some consumers' intolerably poor habits, i.e. not paying off their liabilities on time, whether small or large.

Mortgages were easy to get before the credit crunch, even for borrowers with weak credit scores (Keeley \& Love, 2010, p. 3). In fact, they were so easy that borrowers gave priority to paying back credit-card and car loans before mortgages. With the benefit of hindsight we note that since the credit crunch scoring has been made stricter (Anonymous 2010b, p. 7). 
Despite that rare show of flexibility in easy mortgages, the limits on the degree of social sorting that is to be permitted are normally specific to a particular society: However, the degree of social sorting allowed in that society can be skewed by external factors such as lobbying efforts on the part of companies acting in that particular society to influence the public's views. Such a suspicion arises when one observes the divide in privacy conceptions existing between the Anglo-American cultural sphere and Continental Europe. At least the American consumers trust the private-sector more than their European counterparts would; placing unswerving trust in nation-states, however, can be mistaken too. So, let us look next at the critical trade-off reached between individuality and surveillance.

\section{Individuality and surveillance}

The influential sociologist Anthony Giddens described a rise in individuality as one of the beneficial developments accompanying a post-modern society as compared with a traditional society (Giddens, 1991). Surveillance, on the other hand, is a negatively loaded concept, often considered a threat to privacy. Citizens, e.g. generally dislike being subjected to surveillance, but are likely to accept it as a means of combating terrorism. This paper will look at individuality and surveillance first from the perspective of the nation-state, and then from that of the private sector.

Anthony Giddens' theoretical legacy is said by Frank Webster to come from thought tradtions such as those established by Michel Foucault and Max Weber. Giddens added two sets of "factors in the making of the modern world which the great tradition [had] either understated or overlooked". One of them was heightened surveillance, as Webster recounts the development (Webster, 2002, p. 203). Compared with more traditional societies, "the world in which we live", Giddens observes, "is much more organised than before" (ibid.).

However nation-states require insight into citizens' lives apparently in order to arrange societies efficiently, and their curiosity can be boundless. This has given rise to "surveillance societies" because to organise life, information must be systematically gathered on people and their activities, or as Webster 2002 describes Giddens' view more bluntly, "routine surveillance is a prerequisite of effective social organisation" (Webster, 2002, p. 204).

In fact, "the increasingly organised character of life is a key element of the theory of reflexive modernity" according to Giddens (ibid.). "Crucially, information gathering and analysis allows us to choose our futures upon the basis of 'risk assessment"', as Ulrich Beck described in his 1992 book entitled "The Risk Society", where the term "reflexive modernity" was coined to mean a lookingback on the institutions that had offered members security in a more traditional society before they became modern individuals (Beck, 1992; see also: Webster, 2002, p. 206).

"Modernity being a matter of increased choices made at every level necessitates heightened reflexivity, by which Giddens means increased surveillance (information gathering), so that we may develop knowledge upon which may be made choices about ourselves and the sort of society we want" (Webster, 2002, p. 205).

Thus one of the "paradoxes of modernity" is that "as more is known about people, so individuals may get opportunities to enhance their own individuality by making 'choices' of their own (Webster, 2002, p. 209).

David Lyon has been at the forefront of surveillance studies since the discipline emerged in the Nineties. Webster plots the evolution of the term panopticon back through Lyon as follows: The privacy risks inherent in the new ways of combining disparate databases are reminiscent of the metaphor of the panopticon (Lyon, 1994). The notion was taken up by Foucault (1975) from the original ideas of Jeremy Bentham (Himmelfarb, 1968, in: Webster, 2002, p. 222).

Lyon himself looks back to Gandy 1993 in Lyon's 2002 editorial (Lyon, 2002): Gandy is said to posit an "imperative to surveille lying at the heart of the nation state and the organised lives we live" (Webster, 2002, p. 223). A good historical summary of these linked concepts is available in Zimmer, M. (2007), who also looks back to Gandy (1993), putting him in perspective with Bentham and 
Foucault, and thus developing the latter's panoptic gaze into Gandy's panoptic sort, and adding an update to the Google searches of our time. Lyon devotes a whole chapter to sorting systems (2009, chapter 2), calling them central to surveillance societies because they comprise not just the ID cards themselves, but entire computer systems networked beyond the individual nation state. Lyon develops Zygmunt Bauman's view of the citizen morphing to a mere consumer as this social sorting proceeds in his paper in Haggerty and Samatas eds. 2010 (on pp. 39-47).

Of course, one may wonder whether the interface between the nation-state and its citizens is best positioned in surveillance, or whether there are not less objectionable avenues for this communication. Such avenues have traditionally been seen in the conscription into armies and taxation of citizens within a country's borders as bona fide reasons for surveillance. Giddens and T.H.Marshall (1973) speak of a 'contract' between the nation state and its members, out of which "has emerged a battery of citizenship rights and duties. The main connection with surveillance concerns how these are to be delivered and collected" (Webster, 2002, p. 221). Later sections of this paper will take up again the theme of citizenship and surveillance.

In recent times it has been possible to reconcile these two forces individuality and surveillance: even consumers with low incomes have had the freedom to indulge themselves at the mall, although disciplined by interest rates counter-intuitively kept higher than those for consumers with higher incomes. This development has, of course, in a capitalistic economy involved the private sector.

Ironically, in a society displaying Giddens' reflexive modernity, citizens need surveillance to protect their individuality and thus their privacy. Even worse, surveillance is not limited to the nationstate; it also serves management in the private sector. Like nation-states, private-sector actors are also curious about consumers' lives. Managers need to gather intelligence, such as market research; "A close cousin to such surveillance is credit-checking agencies" (Webster, 2002, pp. 223224).

David Burnham (1983) alerted us to the phenomenon of 'transactional information' some years ago....'a new category of information that automatically documents the daily lives of almost every person (p. 51)' (Webster, 2002, p. 225).

The privacy scholar operating under the pseudonym of Perri6 goes so far as to say that "personal information fuels economic growth" (Perri6 in Lace, 2005, pp. 3, 17).

\section{The Ascent of Credit Scoring Agencies from 1980 to the Financial Crisis of 2007}

Credit scoring is a calculative technique that can be used to sort individuals on the basis of their past credit card spending in an attempt to predict the probability of their paying off a larger future liability such as a mortgage; it is summed up by a proprietary algorithm in a computer-generated numerical "FICO score"1. Private-sector actors (e.g. companies like Equifax and Experian) expanded the system into the main means of weeding out borrowers thought less likely to repay loans than others ${ }^{2}$.

The abuse of privacy in credit scoring dates back to the classic case of Equifax and the Lotus Marketplace (as dealt with in Webster, 2002, p. 144). The product was announced in 1990: eleven CD ROMs in two editions, of which the "Household edition" for Small-to-Medium-sized Enterprises became controversial because it did not include "the same restrictions on the proprietary database

\footnotetext{
${ }^{1}$ For its founders who combined their family names in the Fair Isaac Corporation they set up.

2 "The American information economy has been evolving for decades. Equifax, for example, has been compiling financial histories of consumers for more than a century. Since 1970, use of that data has been regulated by the Federal Trade Commission under the Fair Credit Reporting Act. But Equifax and its rivals started offering new sets of unregulated demographic data over the last decade - not just names, addresses and Social Security numbers of people, but also their marital status, recent births in their family, education history, even the kind of car they own, their television cable service and the magazines they read" reports (Tedeschi, 2009). Tedeschi is a journalist who cites Wu, a staff lawyer at the National Consumer Law Center, a consumer advocacy organization which published the report (Wu, 2009).
} 
of the centralized data brokerage firms" (i.e. Polk, Acxiom, TRW and others) as those that applied in the edition for larger firms.

Today as well, credit scoring agencies are still in the line of critical fire. The story of their role in the subprime mortgage debacle of 2007 is not a simple one, and economists still debate the causes. Conventional wisdom expects that the weaker borrowers defaulted, as the name of the "subprime mortgage crisis" suggests. However, Kuttner claims weaker borrowers were victims instead of wrongdoers (Kuttner, 2009, p. 10). And empirical economic analysis by Demyanyk and Van Hemert describes defaults as irrespective of income strength (Demyanyk \& Van Hemert, 2008; Jaffee, 2008).

"In the early twenty-first century and through the onset of the crisis, blame has fallen on most of the major participants in the domain of mortgage lending: the mortgage brokers, the lenders, the regulators and the borrowers themselves," summarizes Russell 2008 (p. 20). One might add the credit rating agencies as well. ${ }^{3}$ Generally, trade imbalances set the stage (Smadja and Prestowitz, 2010); distorting interest rates. There are a host of other causes of the "credit crunch" ranging from deregulation of financial markets (Kuttner, 2009; Krugman, 2010) to rampant consumerism (Barber, 2007).

The critique leveled in this paper is not directly connected with the causes of the financial meltdown. Instead, this paper strives to establish that a need exists to define social standards for two types of purposes:

- to curb the most egregious abuses, as has been done by passing specific laws in the U.S., and

- new standards to provide better data protection in the applying of credit scoring techniques previously assumed to be "innovative" and beyond reproach.

One Civil Society Organization (CSO) working in the field of microfinance lending cautiously states "The subprime experience reminds us that innovations like credit scoring, outsourcing, and partnership models require care in their implementation" (CGAP, 2008).

Buchmann et al. (2008) go further in positing that if we, as world societies, could reach common ground on data-privacy issues, we could "put pressure on services which violate the privacy of their consumers and [that would] let society enforce social standards for data protection."

The rest of this section will describe various factors leading up to the subprime mortgage crisis of 2007.

After writing chapters of his book on networks, power, identity and dissent, political scientist Paul (Langley, 2008) recalls how credit-scoring agencies served to create smaller risk pools of borrowers, who could be offered higher interest rates. Compared with a wider solidarity society, such a society of small risk pools can afford to expand credit to more members; thus it can appear to be social, and boost consumption and economic growth; see Figure 1.

\footnotetext{
${ }^{3}$ These organizations rate corporations and nation-states as borrowers, and are not to be confused with credit scoring agencies which work on individual borrowers.
} 

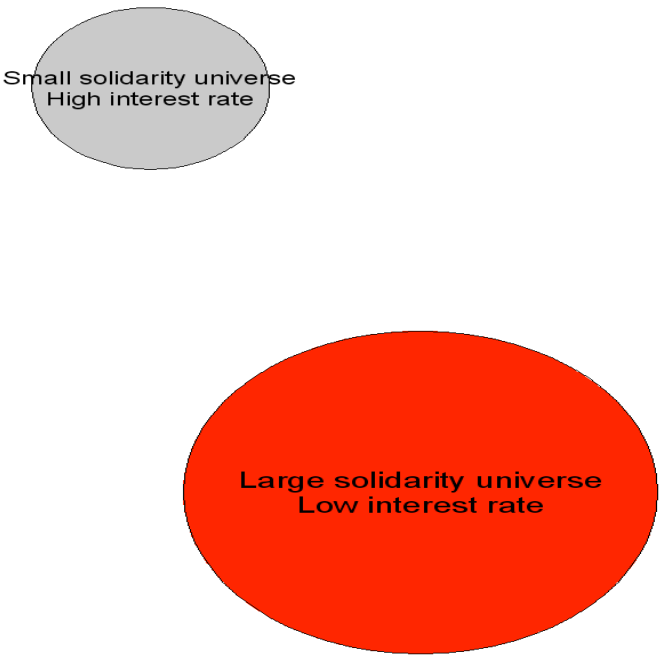

Figure 1: Examples of multiple risk pool types into which a society's borrowers may be differentiated

The small solidarity universe was required to pay higher rates to reflect the higher risk it represented. With the benefit of retrospect, Langley 2008 remarks that "Risk-based pricing failed, in its own terms, to effectively price risk in US sub-prime mortgage networks" (p. 236).

Other factors came into play as well: Automated underwriting took over, for instance, and "IT systems ... led to a 'deskilling of the risk process', as Steve O'Sullivan of Accenture, a consultancy, reported. "At one end of the credit chain, bank employees were not given the proper incentives to review on-screen loan application forms... At the other end computer-generated risk numbers gave executives a false sense of security" (Anonymous, 2009).

The algorithms used to generate the computer numbers representing consumers' real situations were supposed to comprise actuarial fairness, or 'actuarial justice', which has to do with 'statistically-based standards for identifying the dangerous' (Ericson Crime, 2007, cited in Webster, 2002, p. 102).

The automation of mortgage underwriting brought with it increased efficiency in a boom of new contracts. According to economic historian James Clayton 2000 (cited in Langley, 2008, pp. 139ff.) household borrowing in the Group of 7 countries as a percentage of household income rose from $53 \%$ in 1985 to $74 \%$ in 1996 (p. x) during the last three decades of the twentieth century comprising a 'global debt bomb'. In the U.K. "the ratio of households' outstanding obligations to post-tax income increased from roughly 100 to $150 \%$ between the late 1990s and 2005" (Bank of England 2006, p. 39, cited in Langley, 2008, p. 139 ff.).

The default risks from mortgage underwriting were transferred to investors even in other parts of the world through securitization, one of Langley's main themes: "...Transformations in mortgage and consumer credit have realized longer networks so that they now closely overlap and interconnect with the networks of the capital markets in terms of the issue and trading of default risk-related instruments" (Langley, 2008, p. 161).

"The operation of tools of default risk calculation and management, especially asset-backed securitization but also so called 'structured finance' and the use of credit derivatives, turns, then, on the issue and trading of default risk-related instruments in the capital markets", as Langley 2008 realized (p. 153). 
Why were the increased risks not reflected in the holding of larger reserves? The answer to this is complex; one factor was that the Basel II Accord of 2001 was passed as an attempt to limit the practice of moving assets off-balance sheet to provide regulatory capital relief on the liabilities side. But Basel II could not have had much effect in the U.S. in the years leading up to 2007, because the U.S. had not ratified the accord, and still has not done so according to Eichhorn and Solte (2009, p. 232). Basel II has affected credit granted to consumers and Small-to-Medium-sized Enterprises (SMEs). Implementation in the EU Member States has meant that since 2006 consumers can be charged higher interest rates (Anonymous, 2003, p. 33). In the USA that had already been the case for 25 years, i.e. since $1980 .^{4}$

Langley's chapter on dissent and his conclusions chapter both stop short of accusing those who set up the "unprecedented relationships that now bind everyday finance with the capital markets". This stance puts him on a par together with Giddens in partially accepting the rise of surveillance in post modern societies; both of them thus rank farther right than Lyon on a continuum of political ideologies. Lyon is more outspoken and deplores the "social sorting" accomplished by data processing techniques such as credit scoring.

Langley refers to work done by Frank Knight, Sanjay G. Reddy and Timothy Mitchell in distinguishing risk from uncertainty, "the latter as non-calculable future volatilities that are beyond prediction" (Langley, 2008, p. 26). Likewise Nassim Nicholas Taleb upset the ranks of his fellow economists with his 2007 book which was critical of them ${ }^{5}$.

Langley concludes that altering societies' emphasis on managing risk thorough institutions of insurance and pension to ones attempting to manage risk through investment by everybody (marked by the Anglo-American boom in consumer credit and mortgage lending) comprised the backdrop to the financial crisis.

Perri 6 claims that "the advent of the personal information economy has increased [companies'] capability for reducing their exposure [to risk], effectively transferring more risk to consumers as a consequence of knowing those consumers much better" (Perri 6, in: Lace, 2005, p. 31). This comment sums up very well what credit scoring has accomplished.

\section{Credit Scoring in Other Parts of the World}

Thus far we have looked at credit scoring in Anglo-American cultural sphere; but it is spreading to other parts of the world. At a minimum other countries must catch up with the American guardrails governing the applicability of credit scoring (e.g. through a right to be informed and to rectify false entries), and improve on the guardrails in protecting privacy and social justice better. The Obama administration has likewise begun to create a new Consumer Financial Protection Agency (CFPA), as described in U.S. Treasury (2009) and Public Broadcasting System (2009). There the mortgage crisis is embedded in the larger framework of the consumer debt crisis by showing how some consumers laden with excessive credit-card debt resorted to refinancing their homes to get relief, and thus exacerbated the financial crisis; this is confirmed in (Anonymous, 2010, p. 7). The role of consumer debt was for a time underestimated among the causes of the crisis.

After the financial crisis a reporter for "The Economist" reported that "Consumer credit in America ha[d] fallen for ten consecutive months, the largest and longest drop on record" (Anonymous, 2010a, p. 72). Consumer credit had been excessively high prior to that. Credit card systems had burdened U.S. consumers with a level of debt that can no longer be paid off in their lifetimes. Ap-

\footnotetext{
4 "[T]he Depository Institutions Deregulation and Monetary Control Act ("DIDMCA") of $1980 \ldots$ enabled lenders to charge higher interest rates to borrowers with low credit scores" per Russell (p. 18).

${ }^{5}$ For a quick insight into Taleb's thinking, see John Walker: “...[S]o-called 'social scientists'... blithely assume that the Gaussian distribution can be used to model the variability of the things they measure, and that extrapolations from past experience are predictive of the future. The entry of many people trained in physics and mathematics into the field of financial analysis ... swelled the ranks of those who naïvely assume[d] human action behaves like inanimate physical systems," http://www.fourmilab.ch/fourmilog/archives/2009-01/001103.html
} 
parently the drive in the U.S. to boost consumption is part of an unresolved obsession with consumption.

Instead of tempting consumers into more consumption, consumers' appetite for consumption should be tempered through more and better consumer education programs that point to the downside. Germany, for instance, has announced that it intends to launch new consumer protection initiative and publish a Website devoted to scoring ${ }^{6}$. Germany's no. 1 credit scoring company has published a report defending its algorithmic method in two languages. The report points to a crucial difference in cultures: "The German public in general still has a much lower awareness of credit scoring and people do not know what data are relevant for improving their scores. Public anxieties in Germany (and Europe) focus on data protection, a concern with a much lower profile in the U.S." (Rona-Tas \& Hiss, 2008, pp. 27-28).

The sorting accomplished by credit scoring is open to abuses in the marketplace, unless it is tempered by the application of social standards by a regulatory agency. Russell (2008) citing Evanoff and Segal (1996) recounts the social purpose of passing the Community Reinvestment Act in the 1970s "inspired by feelings among community groups". In the case of the crisis of 2007, such excesses as "predatory lending" ing" previously.

A second standard normally applied in the U.S. is that the Credit Scoring Agency must make available to individuals their credit scores (although the algorithms remain proprietary knowledge, and thus "murky").

A third standard is that individuals must be given a means of correcting any errors that creep into their scores from the vast amount of data accumulated. A fourth standard could be that the awareness of the complicated procedures following in credit underwriting should be raised among potential applicants.

In the broader sense, applying social standards to credit scoring entails imposing limits on surveillance. As credit scoring is increasingly used outside the Anglo-American cultural sphere, respect for such standards is likely to become more important. A recent front-page article in the German press, for instance, calls on civil society to wake up and act in preventing Google from expanding its surveillance (Gaschke, 2010).

A further step in research might be to examine more closely the changes made to the AngloAmerican credit scoring model in Continental Europe. In general, Europeans use credit cards much less than Americans. VISA Europe, for instance, has been trying to boost sales ${ }^{10}$. VISA USA resisted at first the terms of the Safe Harbor compromise with the EU (VISA USA, 2000).

On the one hand, countries in Continental Europe have not adopted the American guardrails; only recently has the German consumer protection minister llse Aigner declared the right of all to a free annual credit reporting statement. In many ways, though, EU privacy protection is stronger, or at least EU principles give the appearance of being stronger, although the U.S. implementation of its weaker principles does have some practical advantages for consumers. In some instances, privacy protection is confused with data security; for an example see (Haley, 2009) ${ }^{11}$. This conflict

\footnotetext{
6 "Unter der Adresse www.scoring-verbraucherinfo.de soll zukünftig eine am Schutz der Verbraucher orientierte Information über Scoringverfahren, Auskunfteien, Scoringnutzer, Datenschutz, Fehlerquellen und Korrekturmöglichkeiten von Fehlern erfolgen." (Korczak \& Wilken, 2009, p. 26).

7 "The Act with the most profound effect on the eventual surge in subprime lending was the Community Reinvestment Act ("CRA") of 1977, which was inspired by feelings among community groups that many banks and thrifts were not responding to the credit needs of their communities" (Russell (2008, p. 13).

8 The luring of borrowers into risky contracts with a view to foreclose and obtain property. See also LaVenia, M. (2008) for details on this contested term.

${ }^{9}$ The exclusion of potential borrowers on the basis of their (slum) districts.

${ }^{10}$ In Germany use of the credit card has stagnated at about 5 percent (,Nutzung der Kreditkarte stagniert dagegen bei etwa 5 Prozent") per (Ruhkamp, 2010). This stagnation may not last long, however: "Visa announced in April 2009 an ambitious target to provide one in five euros by electronic means in Europe by 2015, up from the current one in nine," per Euractiv 2010.

${ }^{11}$ Such confusion results partially from the reuse of the German word Datenschutz, literally data protection, in English to mean privacy protection.
} 
over the mismatch of privacy standards has found continuations in episodes involving airlines' Passenger Name Data ${ }^{12}$ and SWIFT financial transactions.

Europeans' distrust of credit cards goes so far that Swiss consumer protection Civil Society Organizations (CSOs) contemplate a discount for payments avoiding credit cards (ACSI, SKS, 2010).

The U.S. guardrails themselves are inadequate even under the laxer U.S. conditions according to an Obama administration initiative (PBS and New York Times, 2009) and an op-ed by Morgenson 2010 concluding there is a "need for a consumer protection agency that has the teeth to police financial institutions' offerings."

With a view to improving on the model, a future paper will address the question as to how appropriate action might be taken, if European citizens seek to apply stricter standards and embed them in a broader framework of privacy governance.

\section{Conclusion}

The evolution of the calculative techniques in effect prior to the subprime mortgage crisis of 2007 may well have been inevitable; the traditional reliance on insurance and pensions was supplanted by a fascination with investment for everybody. Smaller risk pools in computerized credit systems do provide a degree of actuarial fairness. But the crisis laid bare the role of credit-scoring agencies in expanding credit, in boosting economic growth and ultimately -- together with securitization -- in mismanaging risk.

As Taleb (2007) has pointed out above, patterns perceivable in natural science phenomena cannot always be transferred intact to predict human behavior. Young system designers ${ }^{13}$ would do well to temper their command of computer algorithms with a dash of historical experience. Such private-sector players as credit-scoring agencies operate in response to pure market incentives with little regard for values such as data protection and limits on social sorting. As the AngloAmerican practices spread to other countries and cultures, consumers there are likely to demand that abusive players be regulated better, so as to comply better with their respective societies' values.

Consumer education bears promise here. At least one further paper will explore how that might be accomplished in a world of multi-level privacy governance, starting with an analysis of attempts by the Anglo-American of institution of credit scoring to adapt to the quite different privacy conception prevailing in the EU.

\section{References}

6, P. (2002). Global digital communications and the prospects for transnational regulation. Cambridge: Polity Press.

Agre, P. E. \& Rotenberg, M. (1997). "Technology and Privacy: The New Landscape," MIT Press. Retrieved on 4 August, 2010 from https://depts.washington.edu/csclab/critical-technical-practice/

Associazione consumatrici della Svizzera italiana (ACSI). Fédération romande des consommateurs (FRC), Stiftung für Konsumentenschutz (SKS) (2010). Konsumentenagenda der drei Konsumentenorgnisationen ACSI - FRC - SKS für das Jahr 2010, http://preview.tinyurl.com/yc87fy2

Anonymous (2003). "So gibts Kredit", Finanztest 4. Retrieved on 4 August, 2010 from http://preview.tinyurl.com/ylruer6

Anonymous (2009). 'Banks and information technology: Silo but deadly. Messy IT systems are a neglected aspect of the financial crisis'. Retrieved on 4 August, 2010 from

http://www.economist.com/businessfinance/displaystory.cfm?story id =15016132

Anonymous (2010a). World Banking - Digging out of debt, The Economist, 22 January

Anonymous (2010b). Repent at Leisure, Special Report on Debt, $26^{\text {th }}$ June.

Bank of England (2006). Financial Stability Report, London: Bank of England. Retrieved on 4 August, 2010 from http://www.bankofengland.co.uk/publications/fsr/2006/fsrfull0606.pdf

12 For extensive clickable references see Tukdi (2007)

13 Called "technology developers" in Bennett /Raab (2006), p. 220, 229. On pp. 288-289 he cites Agre and Rotenberg (1997) on the persistence of technological paradigms. 
Barber, B. R. (2007). Consumed: How Markets Corrupt Children, Infantilize Adults, and Swallow Citizens Whole. New York: W.W. Norton and Co.

Beck, U. (1992). Risk Society: Towards a New Modernity. London: Sage.

Bennett, C. J. \& Raab, C. D. (2006). The Governance of Privacy: Policy Instruments in Global Perspective. Cambridge, MA: MIT Press.

Buchmann, E., Böhm, K., \& Raabe, O. (2008). Privacy 2.0: Towards Collaborative Data-Privacy Protection. In Trust Management II (pp. 247-262). Boston, MA: Springer.

Burnham, D. (1983). The Rise of the Computer State. New York: Random House

CGAP (2008): Consultative Group to Assist the Poor. The U.S. Subprime Crisis: Five lessons for microfinance, June 26. Retrieved on 4 August, 2010 from http://www2.cgap.org/p/site/c/template.rc/1.26.2705/

Demyanyk, Y. S. \& Van Hemert, O. (2008). Understanding the Subprime Mortgage Crisis. Retrieved on 4 August, 2010 from http://ssrn.com/abstract $=1020396$

Eichhorn, W. \& Solte, D. (2009). Das Kartenhaus Weltfinanzsystem. Frankfurt/Main: Fischer.

Ericson, R. V. (2007). Crime in an Insecure World. Cambridge: Polity.

Euractiv (2010). Payment Services Directive: The end of the cash era? 2010-01-25. Retrieved on 4 August, 2010 from http://preview.tinyurl.com/ycktlbj

Evanoff, D. D. \& Segal, L. M. (1996). CRA and fair lending regulations: Resulting trends in mortgage lending. Economic Perspectives, 20. Retrieved on 4 August, 2010 from http://ideas.repec.org/a/fip/fedhep/y1996inovp1946nv.20no.6.html

Gandy, O. H. (1993). The Panoptic Sort: A Political Economy of Personal Information. Boulder, CO: Westview.

Gaschke, S. (2010). Im Google-Wahn „Der Internetgigant kennt bald jeden unsere Schritte. Es ist Zeit, dass die demokratische Gesellschaft sich wehrt". In: ZEIT, 65 (3), 1.

Giddens, A. (1991). Modernity and Self-Identity. Self and Society in the Late Modern Age. Cambridge: Polity

Haggerty, K. D. \& Samatas, M., (Eds.) (2010). Surveillance and Democracy. London: Routledge.

Haley, M. G. (2009). The Privacy Dilemma: EU Privacy Directive \& Safe Harbor Principles (1 November), "Hospitality Upgrade", Fall Issue. Retrieved on 4 August, 2010 from http://preview.tinyurl.com/358woe6

Jaffee, D. M. (2008). The U.S. Subprime Mortgage Crisis: Issues Raised and Lessons Learned. World Bank. Retrieved on 4 August, 2010 from http://preview.tinyurl.com/34ceofq

Keeley, B. \& Love, P. (2010). From Crisis to Recovery. OECD. Chapter 2 - The Roots of a Crisis. Retrieved on 4 August, 2010 from http://www.oecd.org/dataoecd/32/3/43138294.pdf

Korczak, D. \& Wilken, M. (2009). Verbraucherinformation Scoring. Retrieved on 4 August, 2010 from http://preview.tinyurl.com/3x2p6ow

Krugman, P. (2010). The Third Depression, Op-Ed Column, New York Times (27 June 2010). Retrieved on 4 August, 2010 from http://www.nytimes.com/2010/06/28/opinion/28krugman.html

Kuttner, R. (2009). Financial Regulation After the Fall. Retrieved on 4 August, 2010 from http://preview.tinyurl.com/3xayugw Lace, S. (Ed.) (2005). The Glass Consumer: Life in a Surveillance Society. Bristol: Policy Press

Langley, P. (2008). The Everyday Life of Global Finance: Saving and Borrowing in Anglo-America, Oxford University Press.

LaVenia, M. (2008). Predatory Lending's Role in the Subprime Mortgage Crisis, Developments in Banking and Financial Law: 2006-2007 THE SUBPRIME MORTGAGE CRISIS. In D. Lobel (Ed.) Review of Banking and Financial Law, Volume 27 (pp. 101-110). Retrieved on 4 August, 2010 from http://preview.tinyurl.com/yjau8vn

Lyon, D. (1994). The Electronic Eye: The Rise of Surveillance Society, Cambridge: Polity Press

Lyon, D. (2002). Surveillance Studies: Understanding Visibility, Mobility and the Phenetic Fix, Editorial. Surveillance \& Society, 1(1), 1-7. Retrieved on 4 August, 2010 from http:www.surveillance-and-society.org/articles1/editorial.pdf

Lyon, D. (2009). Identifying Citizens: ID Cards as Surveillance. Cambridge: Polity Press

Marshall, T.H. (1973). Class, Citizenship and Social Development. Westport, CN: Greenwood Press

Morgenson, G. (2010). Fair Game: Credit Cards and Reluctant Regulators, New York Times, 17 January. Retrieved on 4 August, 2010 from http://www.nytimes.com/2010/01/17/business/17gret.html?emc=eta1

Public Broadcasting System (PBS) \& New York Times (2009). Investigating the Massive Consumer Loan Industry and What's Ahead for Customers and Banks. Retrieved on 4 August, 2010 from http://www.pbs.org/wgbh/pages/frontline/creditcards/view/

Reddy, S. G. (1996). Claims to Expert Knowledge and the Subversion of Democracy: The Triumph of rRsk over Uncertainty. Economy and Society, 25(2), 222-254. Retrieved on 4 August, 2010 from http://www.columbia.edu/ sr793/20ClaimstoExpertKnowledge.pdf

Rona-Tas, A. \& Hiss, S. (2008). Consumer and Corporate Credit Ratings and the Subprime Crisis in the U.S. with some Lessons for Germany, Retrieved on 4 August, 2010 from http://www.schufa.de/media/teampresse/publikationen/ronatashiss2008thesubprimecrisis.pdf 
Ruhkamp, S. (2010). Programmierpanne: Vorbehalte gegen die Kreditkarte in: FAZ (9 January). Retrieved on 4 August, 2010 from http://preview.tinyurl.com/ye3cqsd

Russell, J. (2008). Historical Overview of State and Federal Regulation of Mortgage Lending; in: Development in Banking and Financial Law: 2006-2007 The Subprime Mortgage Crisis. In D. Lobel (Ed.) Review of Banking and Financial Law, volume 27 (pp.12-20). http://preview.tinyurl.com/yllzlil or http://preview.tinyurl.com/ylyb4z6

Smadja, C. \& Prestowitz, C. (2010, January 18). Globalization Revolution, Newsweek. Retrieved on 4 August, 2010 from http://www.newsweek.com/id/229962

Taleb, N. N. (2007). The Black Swan, New York: Random House.

Tedeschi, B. (2009, February 8). 'Mortgages: Faulting Credit Firms on Fixing Errors', in print on page RE6 of the New York edition; Retrieved on 4 August, 2010 from http://www.nytimes.com/2009/02/08/realestate/08mort.html

Tukdi, I. (2007). Research Guide on Transatlantic Turbulence: The European Union and United States Debate Over Passenger Data. Retrieved on 4 August, 2010 from http://www.nyulawglobal.org/globalex/Passenger Data US EU.htm

U.S. Treasury (2009). Administration's Regulatory Reform Agenda Moves Forward: Legislation for Strengthening Consumer Protection Delivered to Capitol Hill. Retrieved on 4 August, 2010 from http://www.financialstability.gov/docs/regulatoryreform/consumer protection.pdf

VISA USA (2000). Electronic Mail to United States Department of Commerce Commenting on Draft Safe Harbor Materials by Russell W. Schrader, Esq. 5 April 2000. Retrieved on 4 August, 2010 from http://www.ita.doc.gov/td/ecom/Comments400/VISAcomments.htm

Webster, F. (2002). Theories of the Information Society. New York: Routledge.

Wu, Chi C. (2009). Automated Injustice: How a Mechanized Dispute System Frustrates Consumers Seeking to Fix Errors in Their Credit Reports. Retrieved on 4 August, 2010 from http://preview.tinyurl.com/2fs5lut

Zimmer, M. (2007). The Panoptic Gaze of Web 2.0: How Web 2.0 Platforms Act as Infrastructures of Dataveillance, presented at: Social Software and Web 2.0: Critical Perspectives and Challenges for Research and Business, Aalborg University, Aalborg, Denmark, October 6, 2007. Retrieved on 4 August, 2010 from http://michaelzimmer.org/files/Zimmer\%20Aalborg\%20talk.pdf

\section{About the Author}

Thomas Ruddy

Thomas Ruddy is an American who in the 1990s worked at Saxony Development Corp. for Telematics in Leipzig and on a civil-society initiative to define a way to the Information Society for all of Germany that could be reconciled with sustainable development. His involvement in telematics has included work on RFID and privacy. After 2000 he taught International Political Economy at the Solothurn University of Applied Sciences, Olten, and Webster University Geneva Campus, Switzerland. Since 2002 he has been working as a researcher at Empa Swiss Federal Laboratories for Materials Testing and Research in St.Gallen Switzerland, where his research has focused on the nexus of international trade and sustainable development, especially with regard to the European policy-making arena. He is convener of the project group using the interactive Website on Privacy in E-Governance and Senior Users' Security (PEGASUS), http://pegasuspublic.wikispaces.com 